\title{
Diffuse Source Pollution Studies in a Physical Model of the Severn Estuary, UK
}

\author{
A. Osei-Twumasi ${ }^{*}$, R. A. Falconer ${ }^{2}$ \\ ${ }^{1}$ Department of Civil Engineering, Kumasi Polytechnic, Kumasi, Ghana \\ ${ }^{2}$ Hydro-Environmental Research Centre, Cardiff University, The Parade, Cardiff, UK \\ Email: ${ }^{*}$ Anthony.otwumasi@kpoly.edu.gh
}

Received 8 August 2014; revised 2 September 2014; accepted 28 September 2014

Copyright (C) 2014 by authors and Scientific Research Publishing Inc.

This work is licensed under the Creative Commons Attribution International License (CC BY). http://creativecommons.org/licenses/by/4.0/

(c) (j)

\begin{abstract}
In recent years, there has been growing concern about the impact of diffuse source pollution on water bodies, particularly due to associated health risks. Coastal waters can receive considerable inputs of pollutants from catchments since they serve as sinks for many diffuse pollutants. Furthermore, bathing waters have in the recent past often failed to comply with the various standards set by different bathing water directives. The Severn estuary has recently attracted a lot of attention in terms of bathing water compliance due to its potential to generate a considerable amount of renewable energy for the UK. It is against this background that a physical model of the estuary has been set up in the Hydraulics Laboratory at Cardiff University, for studies to be undertaken to mimic the conditions of the prototype. A sandbox filled with non-cohesive sediments within the laboratory has been set up to investigate the behaviour of pollutants in propagating from the idealised groundwater environment into the estuarine waters. It has been demonstrated that for a semi-diurnal tidal estuary like the Severn, tides have a lesser effect on the transport of solutes than flows from the catchments. Thus the impact of pollution from diffuse sources to marine environments from catchments could be higher in less tidally dominated coastal waters than a tidal one.
\end{abstract}

\section{Keywords}

Diffuse Source, Physical Model, Pollution, Severn Estuary, Tides

\section{Introduction}

The pollution arising from land-use activities that are dispersed across a catchment namely diffuse source pollu-

${ }^{*}$ Corresponding author.

How to cite this paper: Osei-Twumasi, A. and Falconer, R.A. (2014) Diffuse Source Pollution Studies in a Physical Model of the Severn Estuary, UK. Journal of Water Resource and Protection, 6, 1390-1403.

http://dx.doi.org/10.4236/jwarp.2014.615128 
tion can have significant implications on the water quality of the receiving waters [1].

Diffuse sources largely comprise faeces voided directly in fields and animal wastes (e.g. slurry from dairy units) that have been spread to land. Direct voiding of faeces to watercourses also occurs where livestock have access to streams for drinking or at stock crossing points [2].

Diffuse source pollution has been identified in the United States as the biggest challenge in maintaining water quality and is rapidly becoming a major problem in many areas of the UK. Agriculture is considered to be the industry generating the largest amount of diffuse source pollution.

The best estimate of the total amount of agricultural animal manure produced in the world is anywhere between $10^{10}$ and $10^{11}$ tons annually [3] [4]. If managed improperly, it can cause substantial pollution of water. Pathogenic microorganisms that are found in manure can cause serious illness and even death in humans [4] [5]. The manifestations of these microbial pollution sources can be confirmed by: deaths caused by rainfall-induced pathogen movement to a drinking water supply in Canada [6]-[9]; life-threatening illnesses acquired from swimming in US lake water [9] [10], camping on Scottish pasture grazed by sheep [9] [11], paediatric illnesses in the USA acquired from disinfected swimming-pool water [9] [12] [13] and viral infections from a recreational water fountain in the Netherlands [9] [14]. By the frequency of being the cause of water quality impairment, pathogens rank first and second among five leading pollutants in estuaries and rivers, respectively, in the United States [4] [15].

Riverine eutrophication due to diffuse pollution has been identified as a major problem in Ireland [16]. About $87 \%$ of rivers; $50 \%$ of lakes; $35 \%$ of estuaries; $20 \%$ of coastal waters and $68 \%$ of groundwater are at risk of not achieving the objectives set in the Water Framework Directive because of diffuse pollution in the UK [17].

It is now becoming increasingly clear that runoff water generated by rainstorm events carries a variety of pollutants, including faecal indicator bacteria (FIB) from residential, agricultural, or industrial land-use areas, which contribute to elevated pollution levels in receiving waters. It has been demonstrated by many researchers that measurements of indicator bacterial densities are the basis for regulatory decisions regarding recreational and commercial uses of water bodies; however, this contamination is often linked to rain events and resulting storm water runoff from urban and agricultural regions [18]. Rainfall events can increase turbidity, water depth and velocity and therefore reduce the chances of faecal bacteria die-off and sedimentation along watercourses [2]. Faecal indicator organism fluxes are typically around two orders of magnitude greater at high flow than base flow, thereby impacting massively upon microbial pollution concentrations in receiving waters, i.e. lakes and coastal waters [2].

Tide and/or wave induced currents and water level changes frequently exert a significant impact on the movement of shoreline sediments, which can often harbour a significant amount of faecal indicator bacteria [18]. Faecal coliform pollution in coastal waters is a high priority challenge worldwide that has not been completely ameliorated by secondary wastewater treatment [19]. Government regulatory authorities etc. continue to highlight other non-point sources that affect coastal water quality, such as storm-water runoff, septic systems, sanitary sewers and wildlife.

It has been estimated that between 627,800 and 1,479,200 excess gastrointestinal illnesses occur at beaches in Los Angeles and Orange Counties each year due to coastal pollution, corresponding to an annual economic loss of $\$ 51$ million [18] due to such illnesses.

Numerous studies have found that inadequate soil properties, inappropriate site location of onsite wastewater treatment systems like septic tanks and poor management and maintenance techniques can lead to numerous scenarios of system failure and non-compliance. This can lead to contamination of ground and surface water resources due to percolation of inadequately treated sewage effluent from soil based effluent disposal areas [20].

Microbial contamination of water resources is of critical concern due to public health risks [20]. To address the issue of microbial contamination from diffuse inputs, especially from agricultural sources, the use of water quality models come into the fore. Mathematical, process-based system models may be an important tool for hypothesis-building in the search for significant diffuse sources of faecal pollution [19]. Reference [21] states that water quality models are becoming more widely used for developing watershed source water protection plans. However, they concede that the dynamics of microbial pollutant generation and transport within terrestrial and aquatic ecosystems are extremely complicated.

Models that can predict pathogen discharges from catchments are rare [22] [23]. They go on to say that when pathogen modelling is attempted, it is mainly done by an adaptation of more general models that have not been developed specifically for this application. It has been speculated that microbial catchment models are the least 
reliable of all catchment models [23]. Operationally useful, i.e. deterministic and process based, faecal indicator models that are able to predict the effects of individual remedial programmes of measures or best management practices on catchment scale faecal indicator organisms do not exist at the present [9]. Furthermore, it is accepted that catchment microbial modelling is much less well-developed [9] [24]-[26].

Reference [27] advises that the current modelling capability in predicting the impact of diffuse pollution on coastal receiving waters is limited. Whilst it is not difficult to assess and determine point source pollution, diffuse source pollution is a significant challenge because of its widespread distribution over large areas. Although physically based models have been developed [28], they remain difficult to use for watershed planning purposes [21] [29]. The importance of pollution arising out of land-use activities that are dispersed across catchments, has only been recognised recently and the current capability of predicting the impact of diffuse pollution on the aquatic environment is limited [30]. It is possible to mitigate against non-point faecal coliform pollution through source delineation, field studies, system analysis and field management [19]. Diffuse source pollution can be minimised by reducing the connectivity between sources and adjacent watercourses and by improving soil drainage, thereby reducing the volume of surface runoff, which tends to have led to greater faecal indicator organism (FIO) loadings than drain flow [31]. Recent work in Brighouse Bay, Scotland, has shown that significant reductions in FIO concentrations can be achieved where $30 \%$ or more of stream banks within a catchment are fenced [31].

Controlling the production and use of certain hazardous chemicals to stop the pollution at source is a key part of the approach adopted by the UK Environment Agency. Soil protection is also central to reducing water pollution because soils are the route by which many pollutants reach coastal waters [17].

Estuarine environments receive most of the drainage waters coming from the land through fluvial networks and also intermittently shallow marine waters through tidal and wave processes [32]. They therefore become one of the main critical interfaces at the boundary between land and sea and produce an exceptional diversity. Estuary geomorphology strongly affects the transport of pollutants and ultimately impacts on the water quality characteristics [33] [34], with the Severn Estuary being no exception.

A Severn Estuary physical model was therefore constructed in a tidal basin at the Hydraulics Laboratory at Cardiff University, UK. It is significant estuary since it has the second highest tidal range in the world and, in particular, in recent years the estuary has attracted a lot of attention as a potential source of generating considerable quantities of marine renewable energy, particularly from a barrage across the estuary. Thus any studies that can help mimic the hydrodynamics and the pollutant transport conditions in the prototype can potentially assist in addressing many of concerns that the estuary is currently attracting in terms of bathing water pollution. As far as the authors are aware, this physical model study of the Severn Estuary is the first of its kind to have been undertaken to-date.

\section{Methodology}

In the main Severn Estuary the maximum tidal range is $14 \mathrm{~m}$ at Avonmouth (see Figure 1) and the tidal period is typically $12.4 \mathrm{hr}$. Based on [35], the distorted physical model was intended to be designed to give a model tidal range of $12 \mathrm{~cm}$ and a tidal period of $20 \mathrm{~s}$, with a vertical scale of 1:150 and a horizontal scale of 1:25,000, thereby filling the coastal basin at Cardiff University to a maximum. However, this situation could not be achieved in its entirety. The limitations of the coastal basin meant that a tidal range of $10 \mathrm{~cm}$ and a tidal period of $40 \mathrm{~s}$ were the limiting conditions that could be achieved in the physical model. Figure 2 shows the Admiralty Chart 1179 which served as the base map from which the physical model domain was designed, based on a 1:25,000 horizontal scale and 1:125 vertical scale.

Figure 3 is the shape of the physical model that was fitted into the tidal basin for studies to be conducted which is slightly different from the prototype as shown in Figure 1 . The upper reaches of the physical model were slightly turned in the basin domain as shown in Figure 3. Included in this physical model was a $2.0 \mathrm{~m} \times$ $1.2 \mathrm{~m} \times 0.075 \mathrm{~m}$ rectangular box, designed to hold sand and connected to the river and estuary by four small channels as shown in Figure 3. The sandbox was used for the diffuse source pollution studies described herein. Also included in the physical model was a removable model barrage, used to simulate the effects of the proposed structure on the hydrodynamic and solute transport processes in the Severn Estuary. Figure 4 shows the proposed location of the barrage as in the main estuary and as it appears in the physical model as shown in Figure 3. However, the model barrage was not included in the studies reported herein. It has been referenced for completion. Finally, Figure 5 shows the location of the sand-box and the physical model in the coastal basin. 


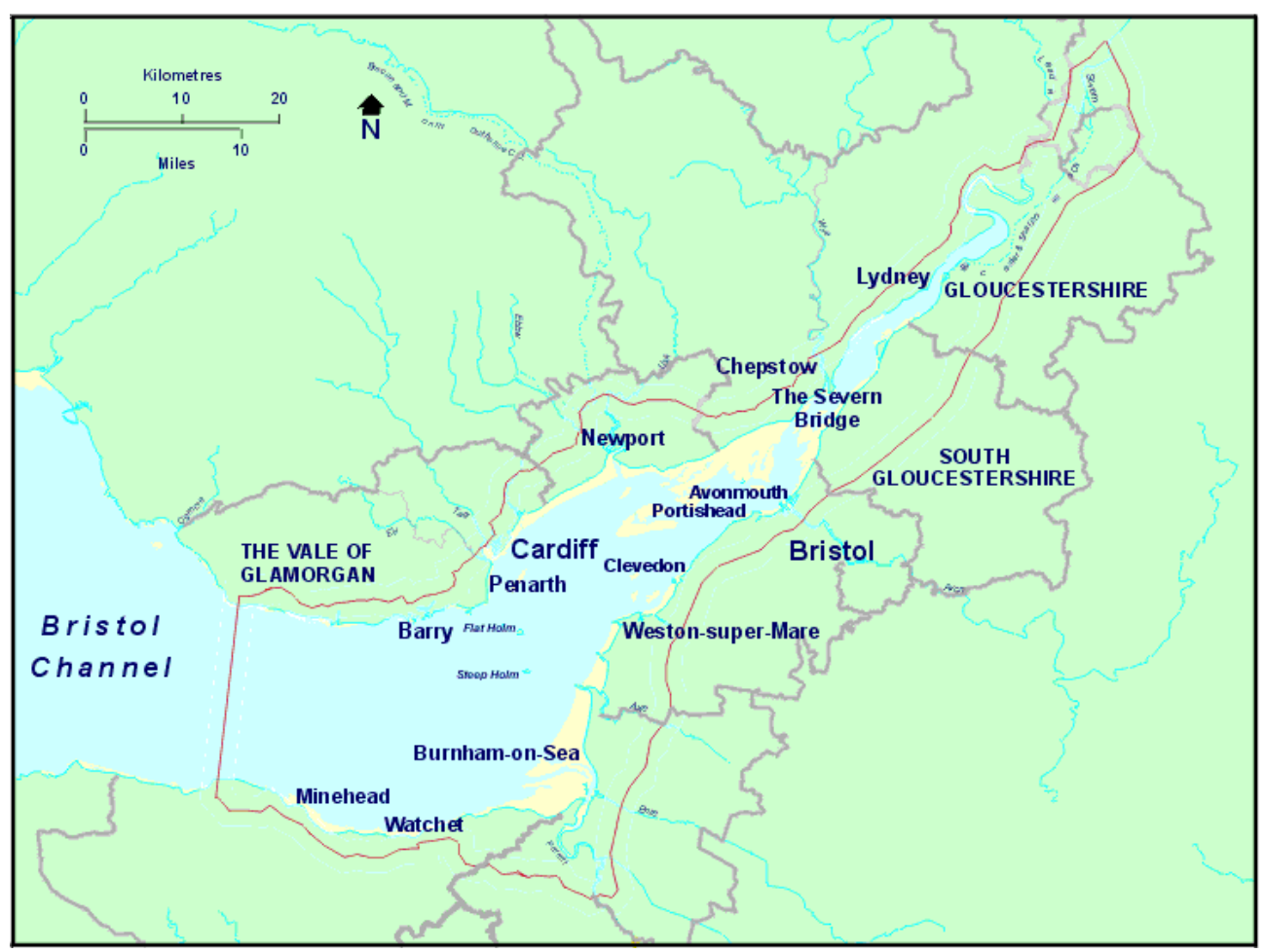

Figure 1. Map of the Bristol Channel and Severn Estuary (Source: Severn Estuary Partnership).

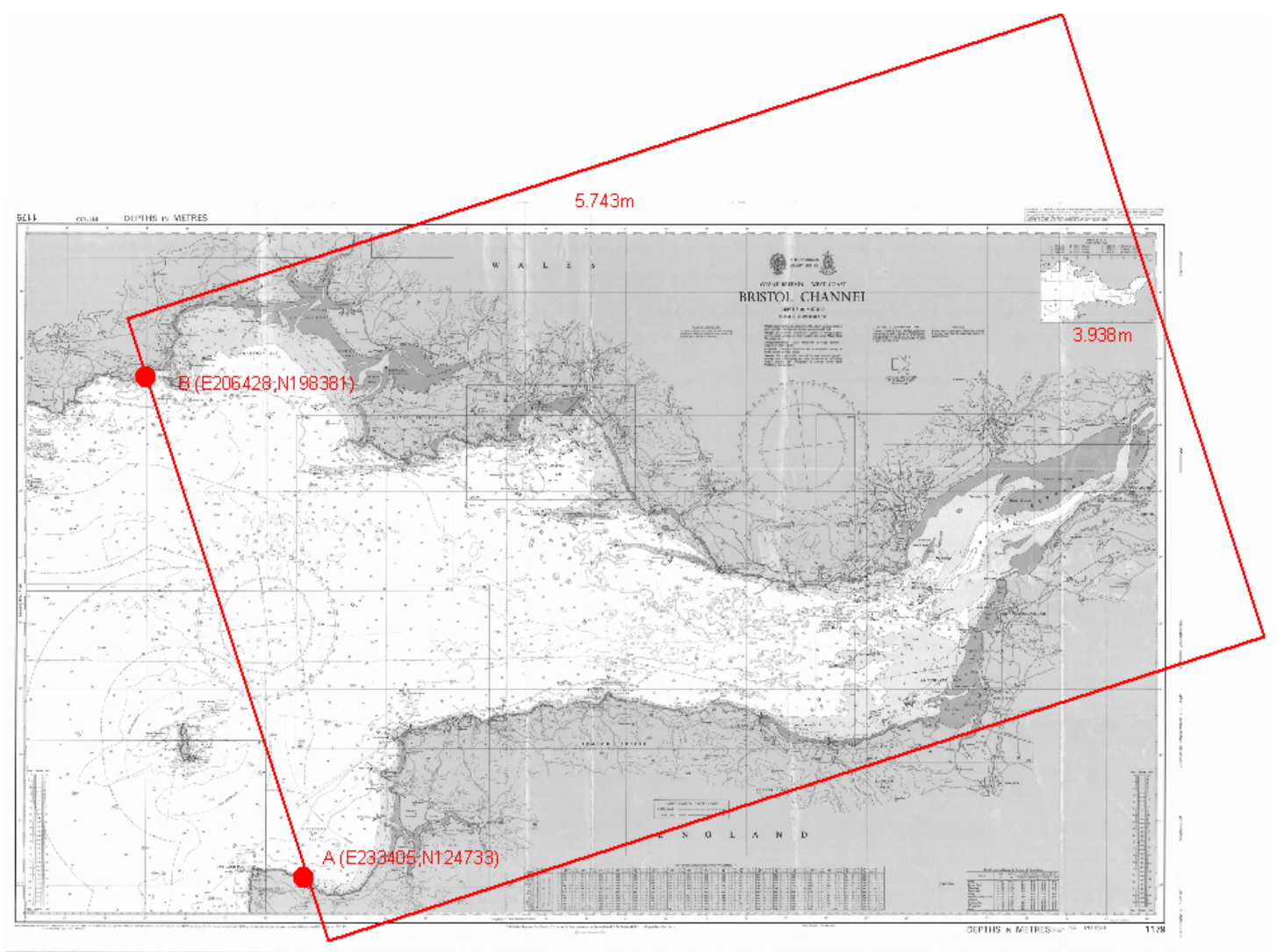

Figure 2. Severn Estuary physical model orientation and domain (Source: Admiralty ChartNP268). 


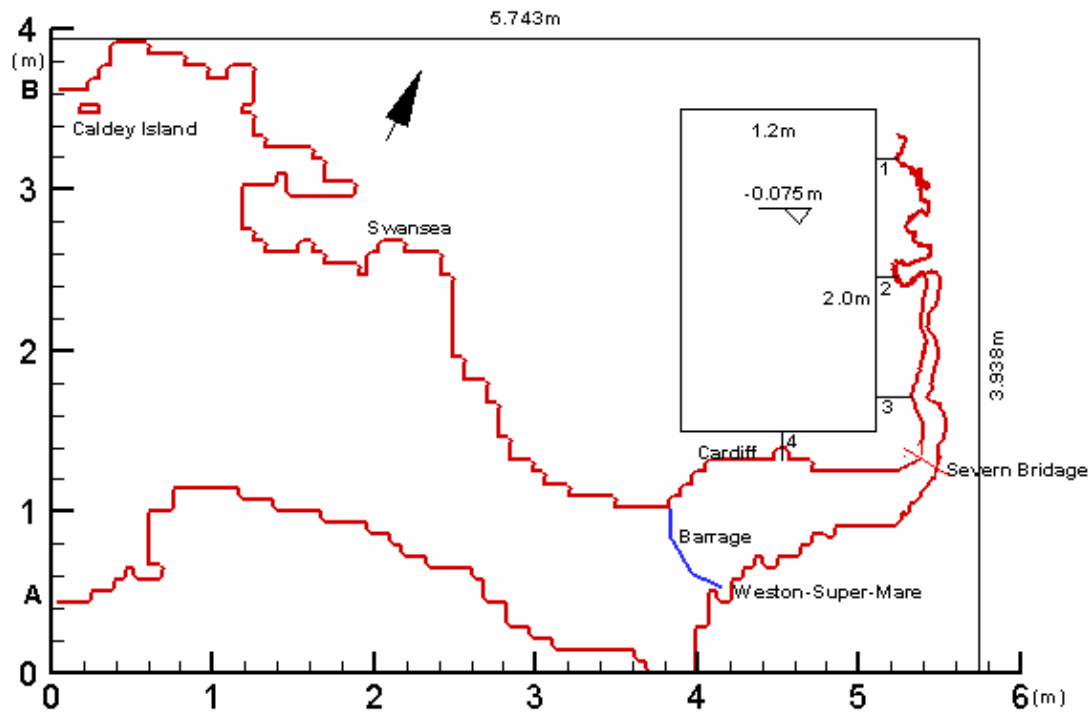

Figure 3. Severn Estuary as sited in the tidal basin, showing the location of the bend in the model.

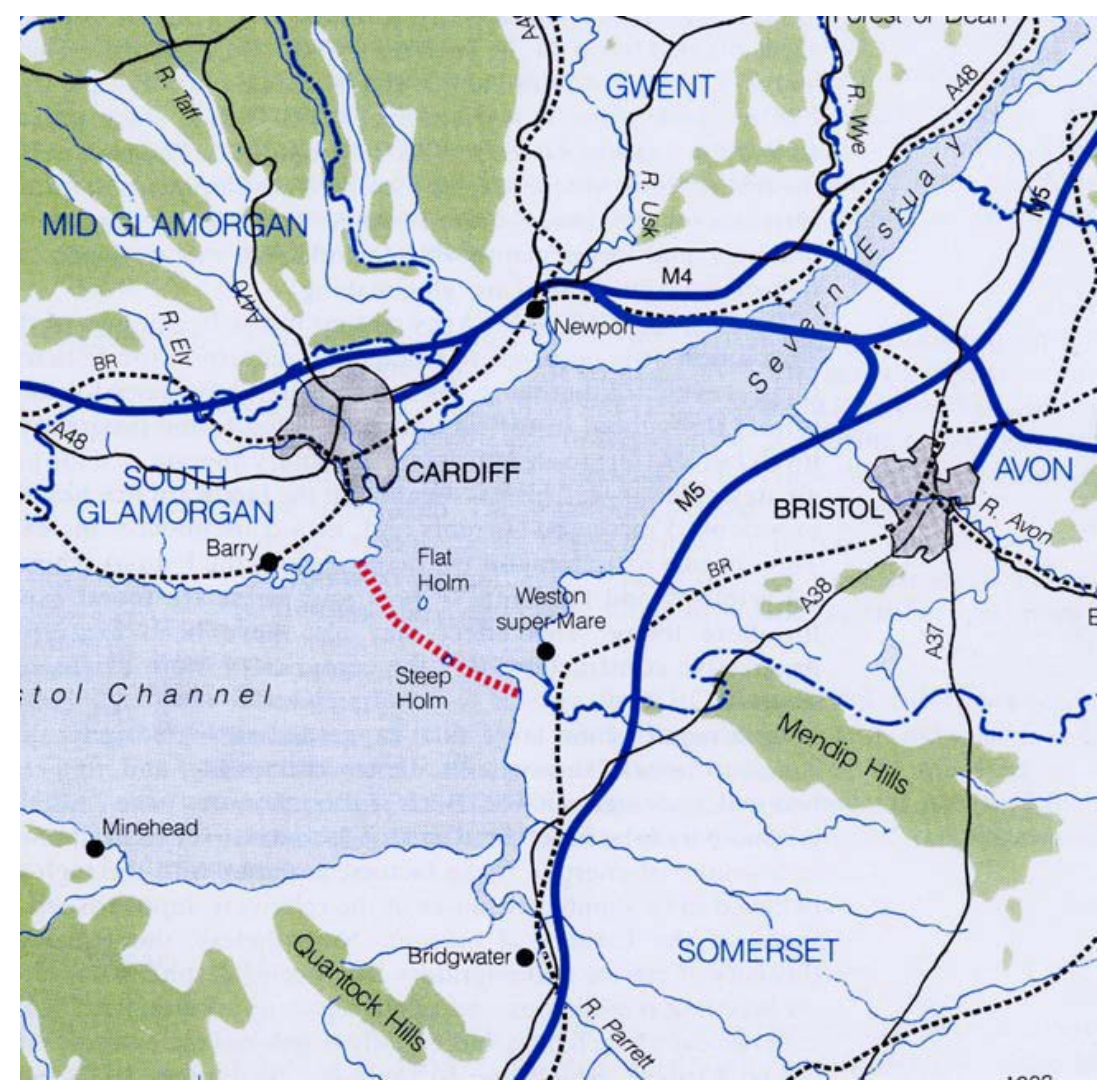

Figure 4. Location of barrage in the main Severn estuary (Source: Severn Tidal Power Group).

\section{Water Level Measurements in the Boreholes}

Figure 6 shows the aerial view of sediments in the sandbox before the tidal cycles were commenced. As shown in Figure 7 (i.e. a section of the sandbox), five holes were drilled into the sediments longitudinally. Metal 


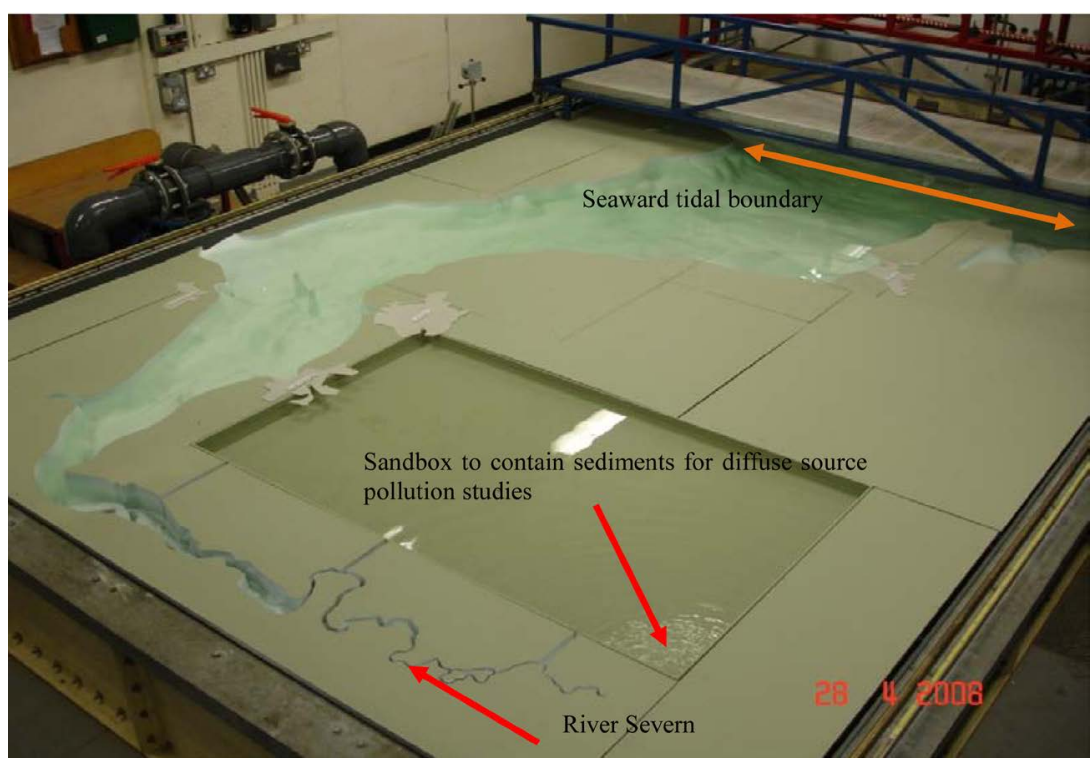

Figure 5. The physical model as laid out in the tidal basin.

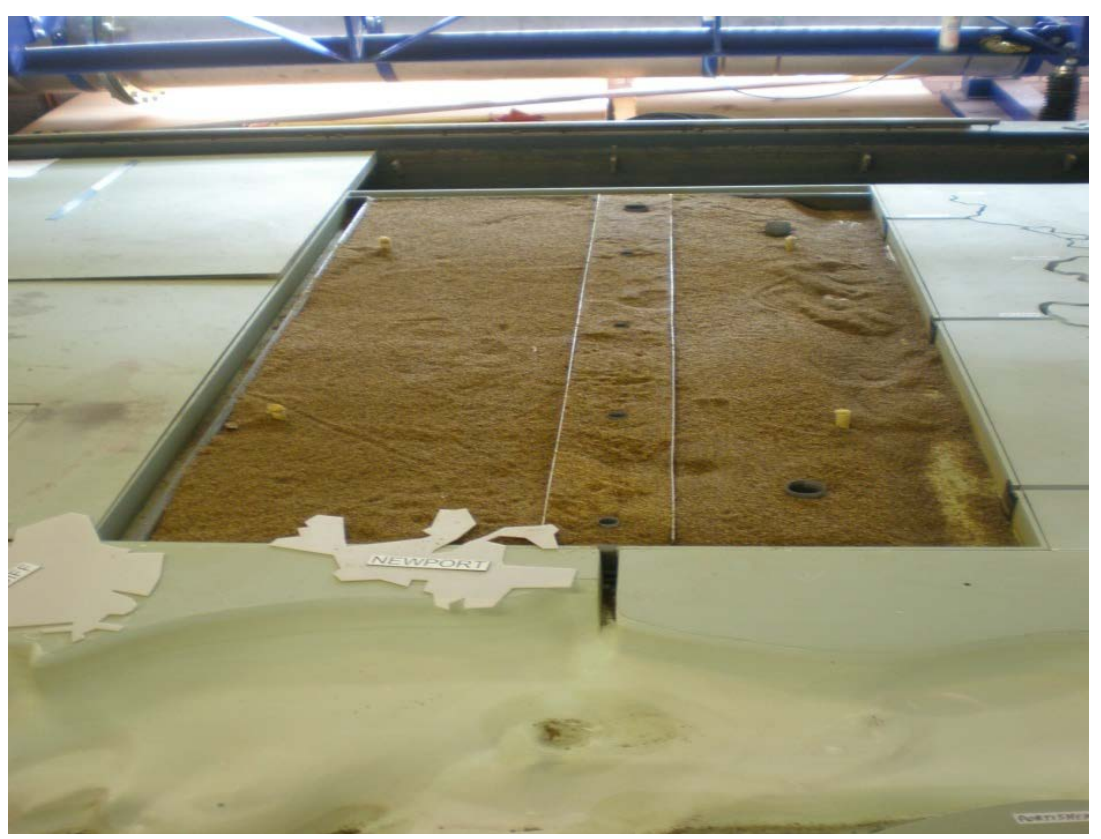

Figure 6. Aerial view of sandbox in the estuary showing holes 1 - 5 and Newport.

barriers were positioned within the sediments to induce a one dimensional flow towards the estuary at point 4 (i.e. corresponding to Newport). A pump was placed at hole 1, with the purpose being to create a head difference between the holes, with the help of an overhead reservoir as shown in Figure 8 and Figure 9, so that the dye moved with the flow when injected. The water continued to flow throuhgout the experiment via hole 1 , and flowed down the idealised river whilst the tides were running. This condition was created in addition to the extra water surface slope generated by the tides, and for both dierections (i.e. during flooding and ebbing). At the outset, water level elevations were measured in each of the holes to evaluate the tidal and river interaction along the basin and especially at the point of discharge, point 4 (Newport).

Figure 10 shows the experimental set-up for collection of data. The dye was injected in hole 2 and observed in holes 4, 5 and at the entrance to the estuary, i.e. at Newport (point 4). Thus water levels were taken simultaneously at these three locations. 


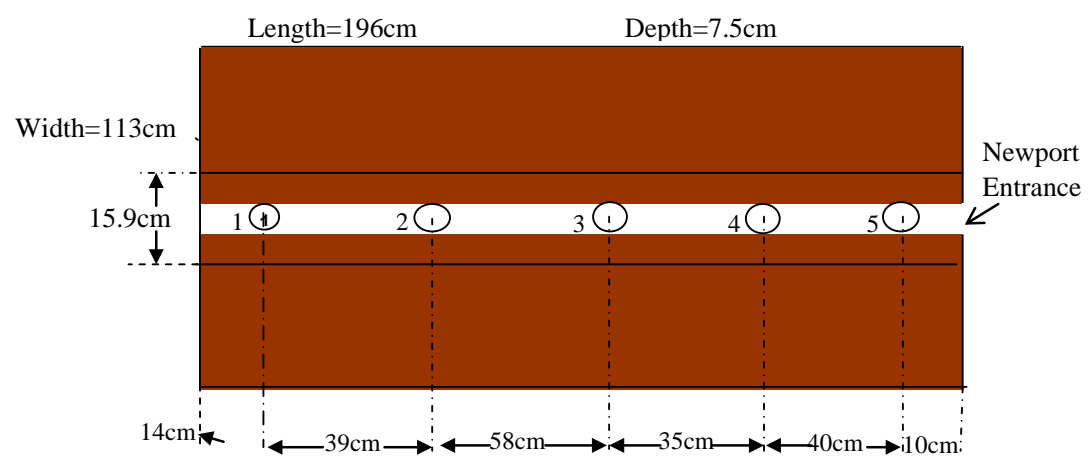

Figure 7. Section through the sandbox showing holes 1 - 5 and Newport entrance (not drawn to scale).

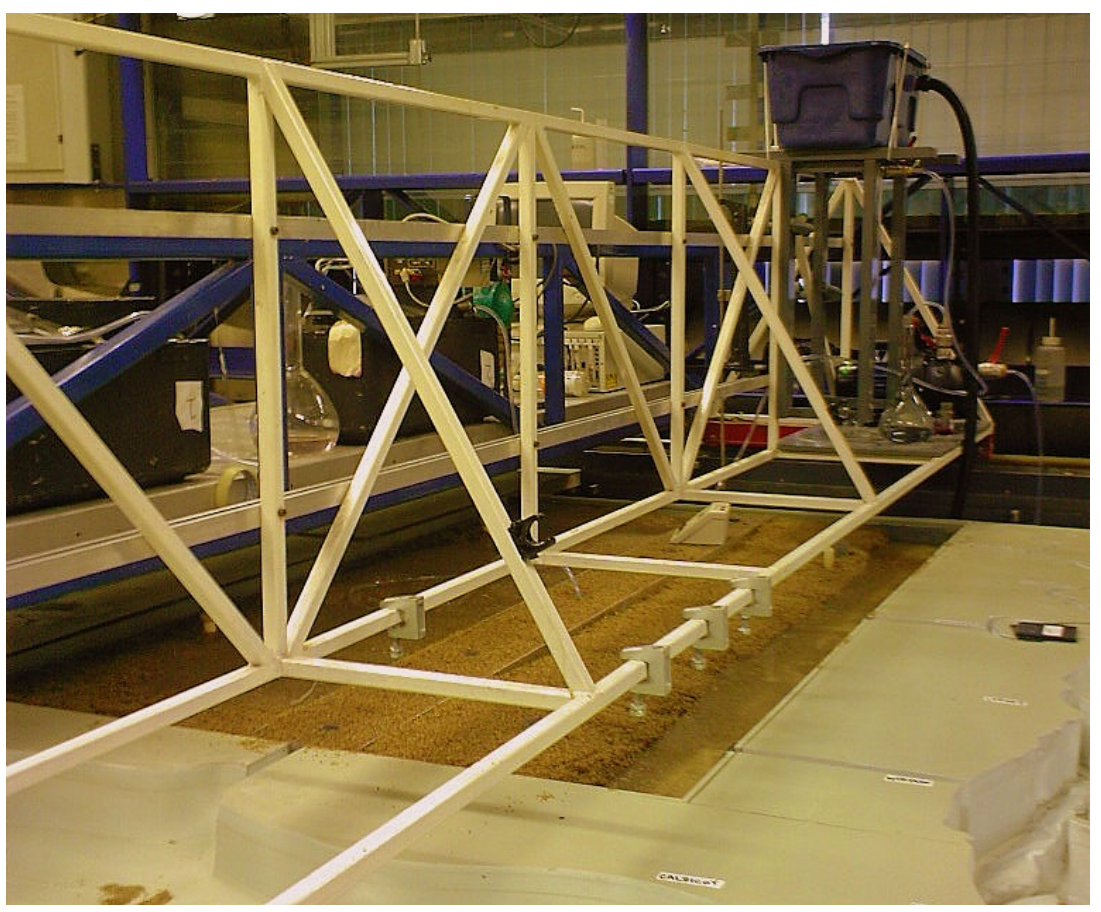

Figure 8. Sandbox in the estuary with the overhead reservoir and all tracer test instrumentation ready for the test.

\section{Tracer Tests Procedure}

The basic testing procedure involved injecting a dye of a known mass into hole 2, while there was an idealised river flow through hole 1 (refer Figure 7). The dye was monitored in holes 4 and 5 and at the estuary entrance, using a fluorometer connected to a pump, and with a tube being placed at the monitoring locations at fixed times. Before the fluorometer was used for the tests, it was calibrated with a well prepared standard dye solution [36]. After the tests, the data were downloaded from the fluorometer via a computer programme for analysis [37]. Figure 11 shows the instrumentation used for the tests, including the fluorometer and the computer used for downloading and recording the data. The pumps, the standard solution (for calibration of the fluorometer), and the tracer were all key to undertaking these tests. During the tests a concentration of 1ppt of Rhodamine WT, with a volume varying between $0.5 \mathrm{ml}$ and $2 \mathrm{ml}$ was used for the injection in hole 1 . The volume of the tracer was decanted into the hole for each individual test. Figure 12 shows the tests about to start in the model estuary. As shown, the pump was connected to a rubber tube in hole 1 as water was allowed to flow and create a head difference. Similarly, the fluorometer was connected to a pump via the rubber tubing for siphoning out the tracer, 


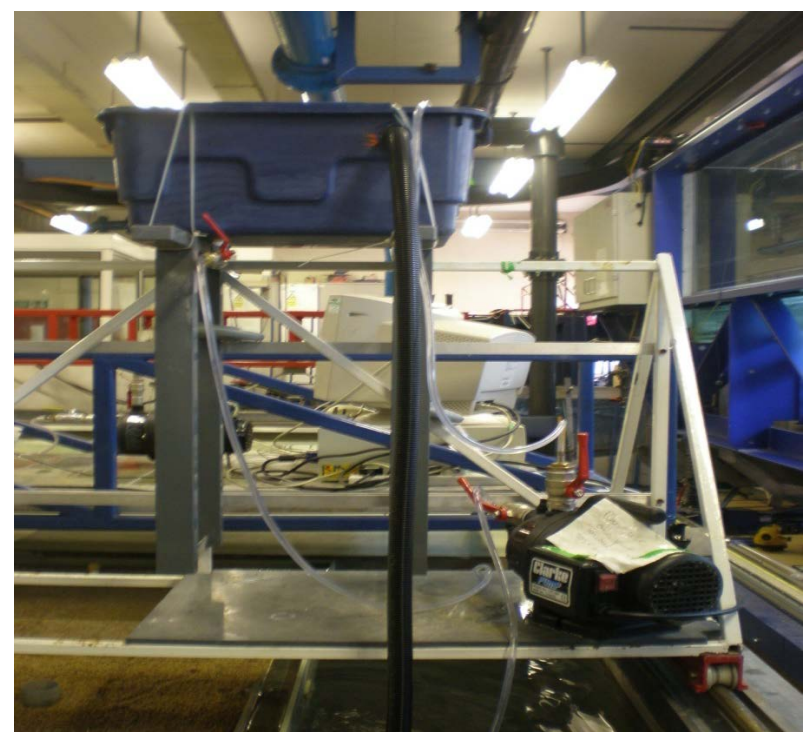

Figure 9. Overhead reservoir creating the head and pump for river flow.

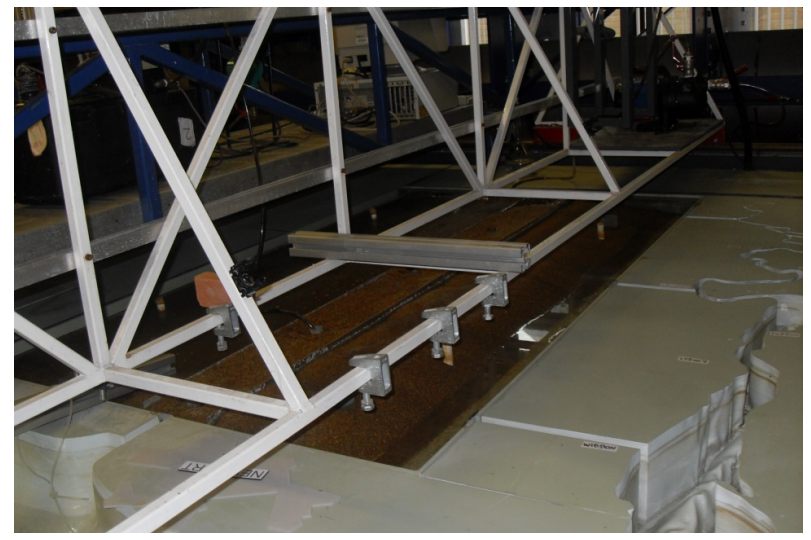

Figure 10. Experimental set up for water level measurement in the sediments.

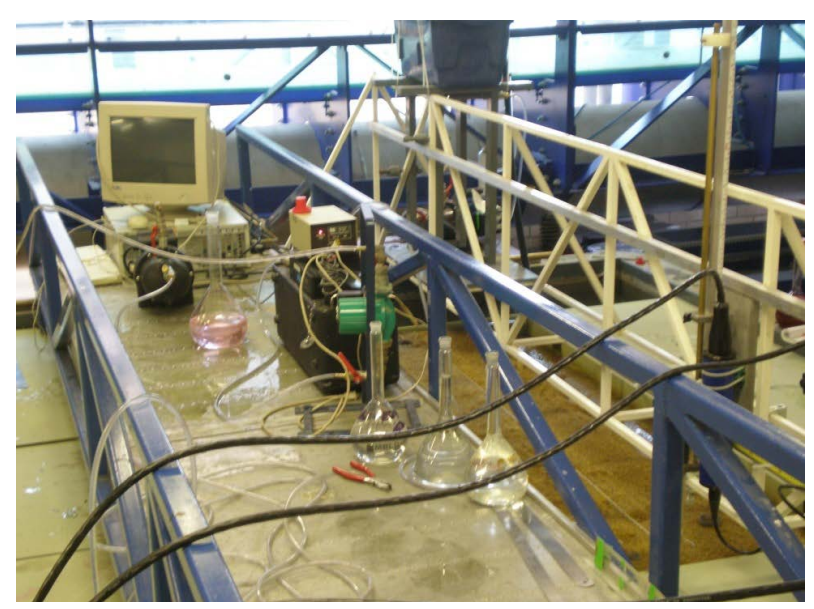

Figure 11. Tracer test instrumentation: pumps, fluorometer, computer for downloading data and standard solution ready for the tests. 


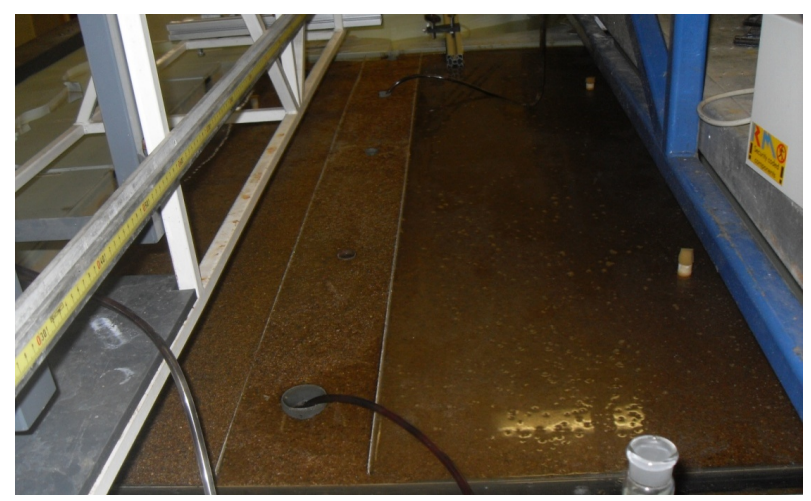

Figure 12. Tracer test in hole 4 with the pump in hole 1.

with the concentration being measured by the instrument. Figure 13 shows the movement of the tracer along the estuary after injection.

\section{Water Level Results}

Figure 14 shows the resulting water level changes for this part of the study. At low tide the head difference between hole 4 and the estuary was $43.1 \mathrm{~mm}$; for hole 4 and hole 5 the difference was $21.7 \mathrm{~mm}$; and between hole 5 and the estuary the level difference was $21.4 \mathrm{~mm}$. However, at high tide the trend was reversed, i.e. after $20 \mathrm{~s}$. For this case, the head difference between hole 5 and the estuary was $-4.6 \mathrm{~mm}$; and that of hole 4 and the estuary was $-22.2 \mathrm{~mm}$, whilst the difference for hole 5 and hole 4 was $17.5 \mathrm{~mm}$. These results showed that for a tidal cycle of $40 \mathrm{~s}$, the flow of water from the sediments to the estuary first ebbed and then reversed after every 20 $\mathrm{s}$ when the tide changed to flood conditions. The flow of water and solute from the sediments was cyclical when the tide changed from flood to ebb, with the cycle repeating itself. This meant that it took a considerable amount of time for much of the solute to be transported from the sediments to the estuary.

\section{Tracer Tests Results}

Figure 15 shows the concentration distributions for all three locations viz holes 4, 5 and Newport. The dye concentration injected in hole 1 was $1 \mathrm{ppt}$ with $0.5 \mathrm{ml}$ in volume. As can be seen from the results, the distributions are normal for each of the tests and they are oscillatory due to the tide. Following the discussion earlier relating to the water elevations, this trend was as expected, since at certain times the tracer would be pushed back by the tide and then flushed out in a cyclical manner, with the shape of the curve being periodic as it follows the same path.

The tracer was observed earlier in hole 4 than in hole 5 and also earlier in hole 5 than in the estuary. This was as expected since hole 4 was the first to occur after injection and then followed by hole 5 and the estuary. The peak concentration in hole 4 is highest amongst the three locations. This is also to be expected since diffusion and dispersion of the tracer as a result of the tide flooding and ebbing would be more pronounced at Newport than at hole 5 and even less so for hole 4. Hence, for the same mass of tracer, the concentration would be higher in hole 4 than in hole 5 and likewise for Newport, as was observed.

Circulation and transport mechanisms in the estuary are complex and subject to a large spatial and temporal variability, derived from the interaction between the river discharge and tidal currents. These forces drive the gravitational circulation and turbulent diffusion, which are the main processes controlling the transport of solutes in estuaries [38]. The bathymetry and shape of the estuary regulates the speed of propagation of tides. Shallow regions of estuaries enable vertical mixing more effectively than deeper regions [33].

Figure 16 shows concentration distribution curves at hole 5, with injection of the same level of concentration, but with different volumes of $0.5 \mathrm{ml}$ and $1 \mathrm{ml}$ respectively. The peak concentration for the $1 \mathrm{ml}$ volume was 790.8 ppb and occurred at 33 mins $25 \mathrm{~s}$ after injection, whereas for the $0.5 \mathrm{ml}$ concentration, the peak concentration was $400 \mathrm{ppb}$ and occurred 33 mins $44 \mathrm{~s}$ after injection. The peak concentration of the latter was about half that of the former, which indicated that the concentration at a point was linearly proportional to the input concentration. The tracer appeared in the hole a little bit earlier for the $1 \mathrm{ml}$ volume than the $0.5 \mathrm{ml}$, as was to be ex- 


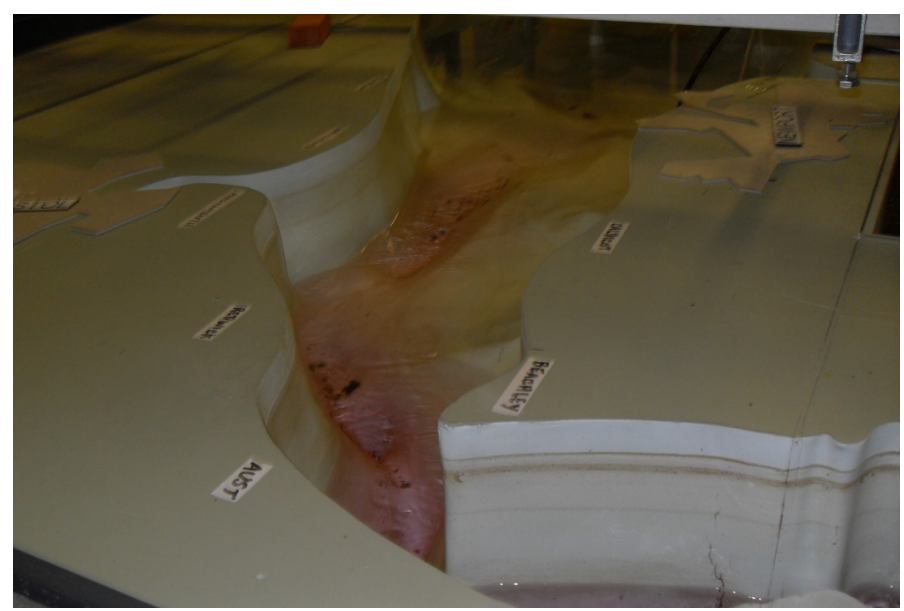

Figure 13. Tracer in the estuary.

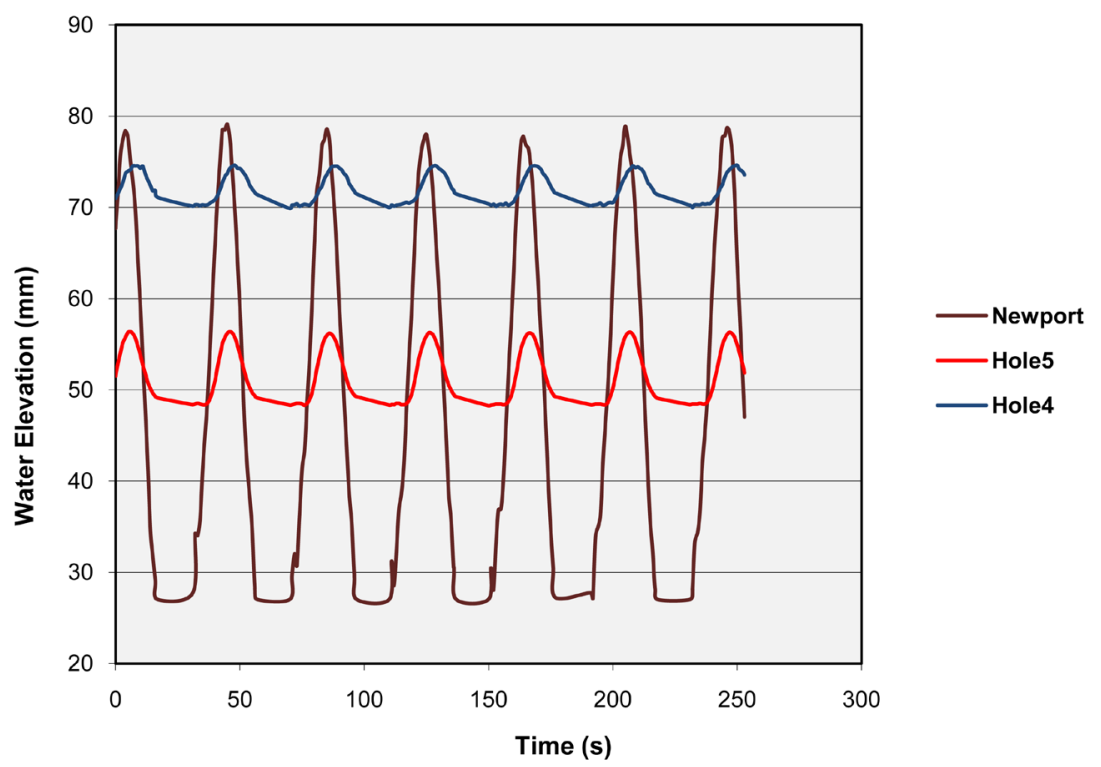

Figure 14. Relative water elevations at holes 4 and 5 and Newport.

pected with the higher concentration and the increased dispersion. The peak concentration was also recorded earlier for the former than the latter. This was again to be expected since the $0.5 \mathrm{ml}$ volume would disperse more rapidly and would have to accumulate a lot more of the dye before recordings could take place. Hence this would take a little more time than for the $1 \mathrm{ml}$ volume concentration.

Finally, the study looked at the effect of the solute transport regime within the sediments without tidal forcing. Figure 17 shows the concentration distribution in holes 4 and 5, with or without tidal forcing. The reason for the peak concentration being higher in hole 4 than in hole 5 has already being discussed. What is significant is the temporal scales in the same hole, with or without tidal effects. In hole 5, the tracer arrived earlier at the observation point for the case where there was no tide than when there was tidal forcing. The same situation was observed in hole 4. As discussed previously, the tide was rapid at this location and at high tide the tracer was pushed back and this phenomenon occurred after every $40 \mathrm{~s}$. In effect, it delayed the flow of solute from the source to the observation point, hence the solute with the river flow only arrived earlier at the monitoring station than the corresponding flow with the tide. This result is in agreement with tracer simulations conducted by [39], which also showed that the residence time for the tracer increased with tidal forcing. As can also be seen from Figure 15, the longitudinal spreading of the plume increased with the tide, and with a lower peak concentration. This result was also similar to the results obtained by [39], whereupon they concluded that tides may decrease 


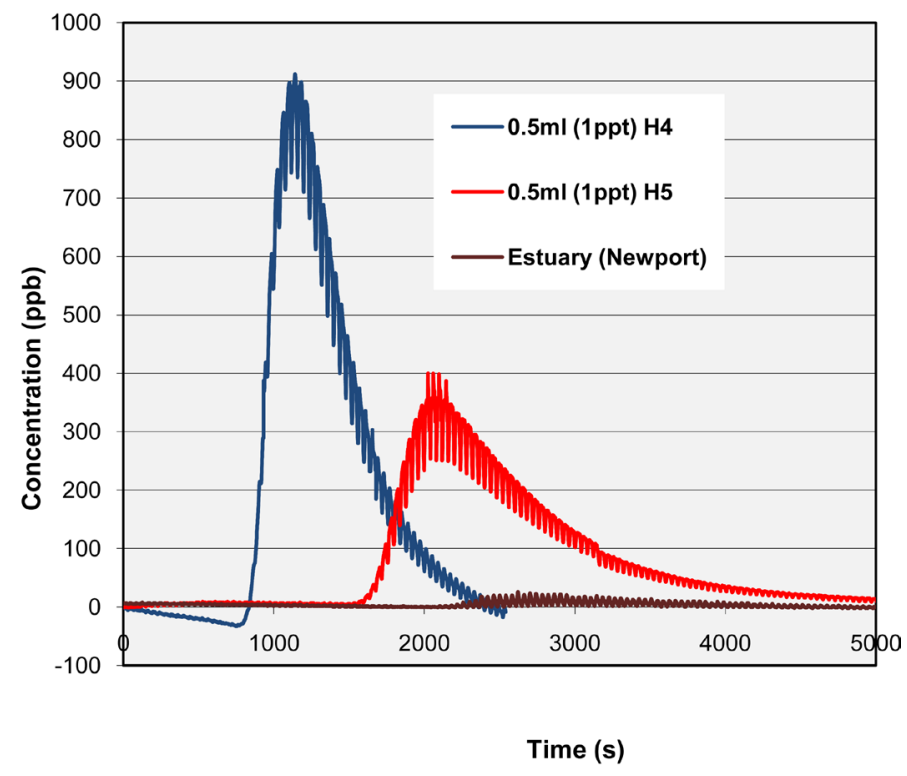

Figure 15. Comparison of concentration distribution at the three locations.

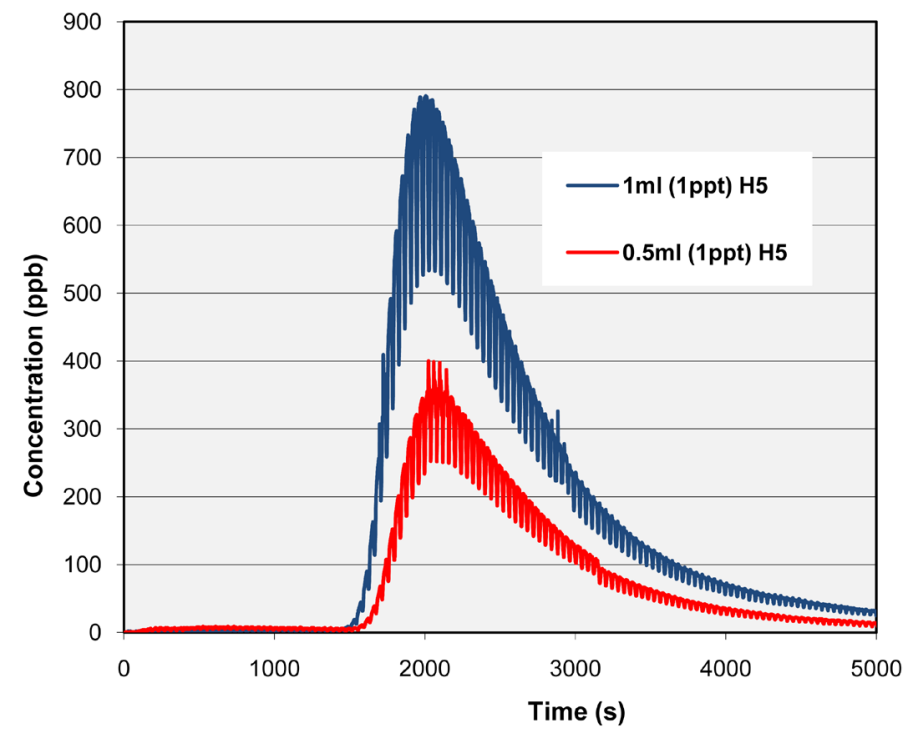

Figure 16. Comparison of concentration distribution at hole 5 for different conditions.

the threat of groundwater-borne pollutants on the marine ecosystem, rather than having the potential to worsen the risk, since tidal effects may also enhance the overall transverse spread of pollutants.

\section{Conclusions and Recommendation}

It has been shown from physical model studies reported herein that for a semi-diurnal tidal estuary, such as the Severn, tides have lesser effect on the transport of solutes than from river flows in catchments. Thus the impact of pollution from diffuse sources to marine environments from catchments could be higher in less tidally dominated coastal waters than in a basin which has a relatively high tidal range. This conclusion is consistent with simulations from [39]. Also the spatial extent of the pollutant tracer was found to be minimised within the estuary as the tide tended to flush the pollutants back and forth along the estuary or coastal zone. 


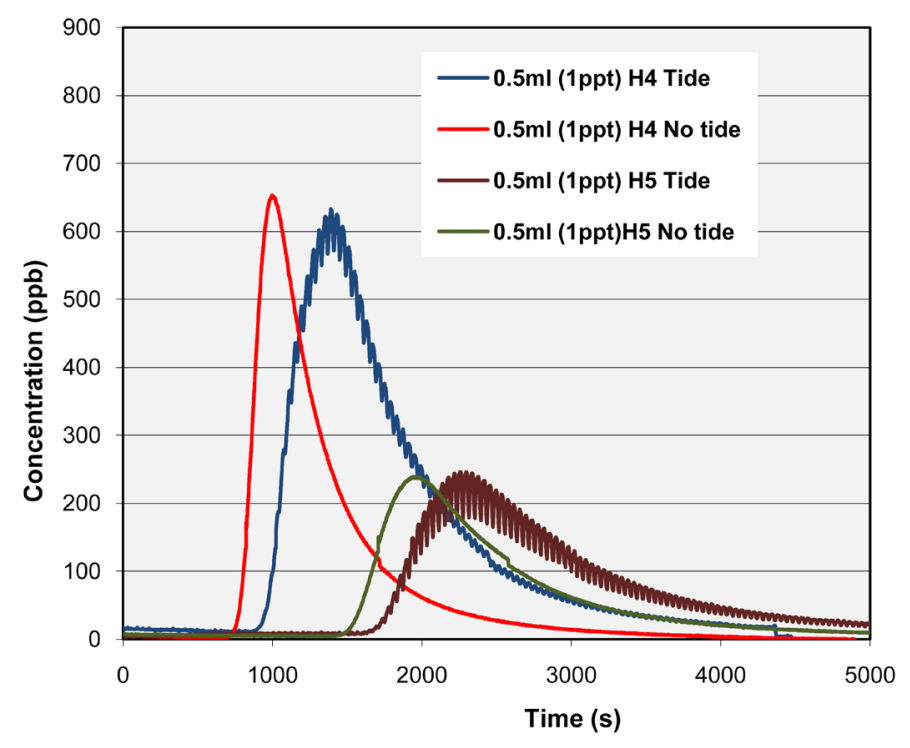

Figure 17. Comparison of concentration distribution for hole 4 and 5 with and without tidal forcing.

The purpose of the sand box with the included sediments, and attached to the Severn Estuary physical model, was to look at the impact of diffuse source pollution from catchments on the marine environment and under controlled laboratory conditions. In this study, however, a one dimensional pollution pathway was created to link the sediments to the estuary for the studies to be conducted. This may not replicate the real situation in the river basin that well. It is therefore recommended that a catchment model be linked to the existing 1D-2D DIVAST estuary model for detailed knowledge and analysis of the impact of pollution from such sources on coastal waters.

\section{Acknowledgements}

The second author is grateful to CH2M HILL for the support provided to the Hydro-environmental Research Centre and to part of the laboratory facilities provided for this study. The authors are also grateful to Mr. Paul Leach for his technical assistance and support.

\section{References}

[1] Schnauder, I., Bockelmann-Evans, B. and Lin, B. (2007) Modelling Faecal Bacteria Pathways in Receiving Waters. Proceedings of the Institution of Civil Engineers, Maritime Engineering, 160, 143-153. http://dx.doi.org/10.1680/maen.2007.160.4.143

[2] Kay, D., Crowther, J., Stapleton, C.M., Wyer, M.D., Fewtrell, L., Anthony, S., et al. (2008) Faecal Indicator Organism Concentrations and Catchment Export Coefficients in the UK. Water Research, 42, 2649-2661. http://dx.doi.org/10.1016/j.watres.2008.01.017

[3] Fayer, R. and Trout, J.M. (2005) Zoonotic Protists in the Marine Environment. In: Belkin, S.S. and Cowell, R., Eds., Oceans and Health: Pathogens in Marine Environment, Kluwer Academic Publishers, Dordrecht, 143-163.

[4] Pachepsky, Y.A., Sadeghi, A.M., Bradford, S.A., Shelton, D.R., Guber, A.K. and Dao, T. (2006) Transport and Fate of Manure-Borne Pathogens: Modeling Perspective. Agricultural Water Management, 86, 81-92. http://dx.doi.org/10.1016/j.agwat.2006.06.010

[5] Cotruvo, J.A., Dufour, A., Rees, G., Bartram, J., Carr, R., Cliver, D.O., et al., Eds. (2004) Waterborne Zoonoses: Identification, Causes and Control. IWA Publishing, London.

[6] Danon-Schaffer, M.N. (2001) Walkerton's Contaminated Water Supply System: A Forensic Approach to Identifying the Source. Environmental Forensics, 2, 197-200. http://dx.doi.org/10.1006/enfo.2001.0054

[7] Holme, R. (2003) Drinking Water Contamination in Walkerton, Ontario: Positive Resolutions from a Tragic Event. Water Science and Technology, 47, 1-6.

[8] Auld, H., MacIver, D. and Klaassen, J. (2004) Heavy Rainfall and Waterborne Disease Outbreaks: The Walkerton 
Example. Journal of Toxicology and Environmental Health Part A, 67, 1879-1887. http://dx.doi.org/10.1080/15287390490493475

[9] Kay, D., Edwards, A.C., Ferrier, R.C., Francis, C., Kay, C., Rushby, L., et al. (2007) Catchment Microbial Dynamics: The Emergence of a Research Agenda. Progress in Physical Geography, 31, 59-76. http://dx.doi.org/10.1177/0309133307073882

[10] Bruce, M.G., Curtis, M.B., Payne, M.M., Gautom, R.K., Thompson, E.C., Bennett, A.L. and Kobayashi, J.M. (2003) Lake-Associated Outbreak of Escherichia coli O157:H7 in Clark County, Washington, August 1999. Archives of Pediatric and Adolescent Medicine, 157, 1016-1021. http://dx.doi.org/10.1001/archpedi.157.10.1016

[11] Ogden, I.D., Hepburn, N.F., MacRae, M., Strachan, N.J.C., Fenlon, D.R., Rusbridge, S.M. and Pennington, T.H. (2002) Long-Term Survival of Escherichia coli O157 on Pasture Following an Outbreak Associated with Sheep at a Scout Camp. Letters in Applied Microbiology, 34, 100-104. http://dx.doi.org/10.1046/j.1472-765x.2002.01052.x

[12] Castor, M.L. and Beach, M.J. (2004) Reducing Illness Transmission from Disinfected Recreational Water Venues: Swimming, Diarrhea and the Emergence of a New Public Health Concern. Pediatric Infectious Diseases Journal, 23, 866-870. http://dx.doi.org/10.1097/01.inf.0000138081.84891.30

[13] Lim, L.S., Varkey, P., Giesen, P. and Edmonson, L. (2004) Cryptosporidiosis Outbreak in a Recreational Swimming Pool in Minnesota. Journal of Environmental Health, 67, 16-20.

[14] Hoebe, C., Vennema, H., Husman, A.M.D. and van Duynhoven, Y. (2004) Norovirus Outbreak among Primary Schoolchildren Who Had Played in a Recreational Water Fountain. Journal of Infectious Diseases, 189, 699-705. http://dx.doi.org/10.1086/381534

[15] EPA (2004) Potential Environmental Impacts of Animal Feeding Operations. http://www.epa.gov/agriculture/ag101/impacts.html

[16] Earle, J.R. (2003) The Three Rivers Project-Water Quality Monitoring and Management Systems in the Boyne, Liffey and Suir Catchments in Ireland. Water Science and Technology, 47, 217-225.

[17] Environment Agency (2007) The Unseen Threat to Water Quality. Diffuse Water Pollution in England and Wales Report. Environment Agency, Bristol.

[18] He, L.M. and He, Z.L. (2008) Water Quality Prediction of Marine Recreational Beaches Receiving Watershed Baseflow and Stormwater Runoff in Southern California, USA. Water Research, 42, 2563-2573. http://dx.doi.org/10.1016/j.watres.2008.01.002

[19] Steets, B.M. and Holden, P.A. (2003) A Mechanistic Model of Runoff Associated Fecal Coliform Fate and Transport through a Coastal Lagoon. Water Research, 37, 589-608. http://dx.doi.org/10.1016/S0043-1354(02)00312-3

[20] Carroll, S.P., Dawes, L., Hargreaves, M. and Goonetilleke, A. (2009) Faecal Pollution Source Identification in an Urbanising Catchment Using Antibiotic Resistance Profiling, Discriminant Analysis and Partial Least Squares Regression. Water Research, 43, 1237-1246. http://dx.doi.org/10.1016/j.watres.2008.12.017

[21] Sinclair, A., Hebb, D., Jamieson, R., Gordon, R., Benedict, K., Fuller, K., Stratton, G.W. and Madani, A. (2009) Growing Season Surface Water Loading of Fecal Indicator Organisms within a Rural Watershed. Water Research, 43, 1199-1206. http://dx.doi.org/10.1016/j.watres.2008.12.006

[22] Ferguson, C., Husman, A., Altavilla, N., Deere, D. and Ashbolt, N. (2003) Fate and Transport of Surface Water Pathogens in Watersheds. Critical Reviews in Environmental Science and Technology, 33, 299-361. http://dx.doi.org/10.1080/10643380390814497

[23] Haydon, S. and Deletic, A. (2009) Model Output Uncertainty of a Coupled Pathogen Indicator-Hydrologic Catchment Model Due to Input Data Uncertainty. Environmental Modelling \& Software, 24, 322-328. http://dx.doi.org/10.1016/j.envsoft.2008.09.004

[24] Crowther, J., Kay, D. and Wyer, M.D. (2002) Faecal-Indicator Concentrations in Waters Draining Lowland Pastoral Catchments in the UK: Relationships with Land Use and Farming Practices. Water Research, 36, 1725-1734. http://dx.doi.org/10.1016/S0043-1354(01)00394-3

[25] Crowther, J., Wyer, M.D., Bradford, M., Kay, D. and Francis, C.A. (2003) Modelling Faecal Indicator Concentrations in Large Rural Catchments Using Land Use and Topographic Data. Journal of Applied Microbiology, 94, 962-973. http://dx.doi.org/10.1046/j.1365-2672.2003.01877.x

[26] Kay, D., Wyer, M.D., Crowther, J., Stapleton, C.M., Bradford, M., McDonald, A.T., et al. (2005) Predicting Faecal Indicator Fluxes Using Digital Land Use Data in the UK's Sentinel Water Framework Directive Catchment: The Ribble Study. Water Research, 39, 3967-3981. http://dx.doi.org/10.1016/j.watres.2005.07.006

[27] Yuan, D., Lin, B., Falconer, R.A. and Tao, J. (2007) Development of an Integrated Model for Assessing the Impact of Diffuse and Point Source Pollution on Coastal Waters. Environmental Modelling \& Software, 22, 871-879. http://dx.doi.org/10.1016/j.envsoft.2006.05.010 
[28] Kashefipour, S.M., Lin, B., Harris, E.L. and Falconer, R.A. (2002) Hydro-Environmental Modelling for Bathing Water Compliance of an Estuarine Basin. Water Research, 36, 1854-1868. http://dx.doi.org/10.1016/S0043-1354(01)00396-7

[29] Jamieson, R., Gordon, R., Joy, D. and Lee, H. (2004) Assessing Microbial Pollution of Rural Surface Waters: A Review of Current Watershed Scale Modeling Approaches. Agricultural Water Management, 70, 1-17. http://dx.doi.org/10.1016/j.agwat.2004.05.006

[30] Ebrahimi, K. (2004) Development of an Integrated Free Surface and Groundwater Flow Model. Ph.D. Thesis, Cardiff University, Cardiff.

[31] Kay, D., Aitken, M., Crowther, J., Dickson, I., Edwards, A.C., Francis, C., et al. (2007) Reducing Fluxes of Faecal Indicator Compliance Parameters to Bathing Waters from Diffuse Agricultural Sources: The Brighouse Bay Study, Scotland. Environmental Pollution, 147, 138-149. http://dx.doi.org/10.1016/j.envpol.2006.08.019

[32] Traini, C., Menier, D. and Proust, J.N. (2008) The Vilaine River Estuary in the Bay of Biscay: Insight into Geomorphologic Controls on Estuarine Sedimentation. EGU General Assembly, Geophysical Research Abstracts, Vol. 10, EGU2008-A-05586.

[33] Manoj, N.T. (2008) Numerical Modelling of Tidal Circulation and Studies on Salinity Distribution in Mandovi and Zuari Estuaries. Ph.D. Thesis, Goa University, Goa.

[34] Martin, J.L. and McCutcheon, S. (1999) Hydrodynamics and Transport for Water Quality Modeling. CRC Press, Inc., Florida.

[35] Jiang, J.X. and Falconer, R.A. (1983) On the Tidal Exchange Characteristics of Model Rectangular Harbours. Proceedings of the Institution of Civil Engineers, Part 2, Research and Theory, 75, 475-489. http://dx.doi.org/10.1680/iicep.1983.1441

[36] Turner_Designs (2006) Application Support Bulletin 103: Fluorescein and a Fluorometer. http://www.turnerdesigns.com/t2/doc/appnotes/998_5103.html

[37] Turner_Designs (2006) Application Support Bulletin 104: Fluorescent Tracer Dyes. http://www.turnerdesigns.com/t2/doc/appnotes/998_5104.html

[38] Mantovanelli, A., Marone, E., da Silva, E.T., Lautert, L.F., Klingenfuss, M.S., Prata Jr., V.P., et al. (2004) Combined Tidal Velocity and Duration Asymmetries as a Determinant of Water Transport and Residual Flow in Paranaguá Bay Estuary. Estuarine, Coastal and Shelf Science, 59, 523-537. http://dx.doi.org/10.1016/j.ecss.2003.09.001

[39] Robinson, C., Li, L. and Barry, D.A. (2007) Effect of Tidal Forcing on a Subterranean Estuary. Advances in Water Resources, 30, 851-865. http://dx.doi.org/10.1016/j.advwatres.2006.07.006 
Scientific Research Publishing (SCIRP) is one of the largest Open Access journal publishers. It is currently publishing more than 200 open access, online, peer-reviewed journals covering a wide range of academic disciplines. SCIRP serves the worldwide academic communities and contributes to the progress and application of science with its publication.

Other selected journals from SCIRP are listed as below. Submit your manuscript to us via either submit@scirp.org or Online Submission Portal.
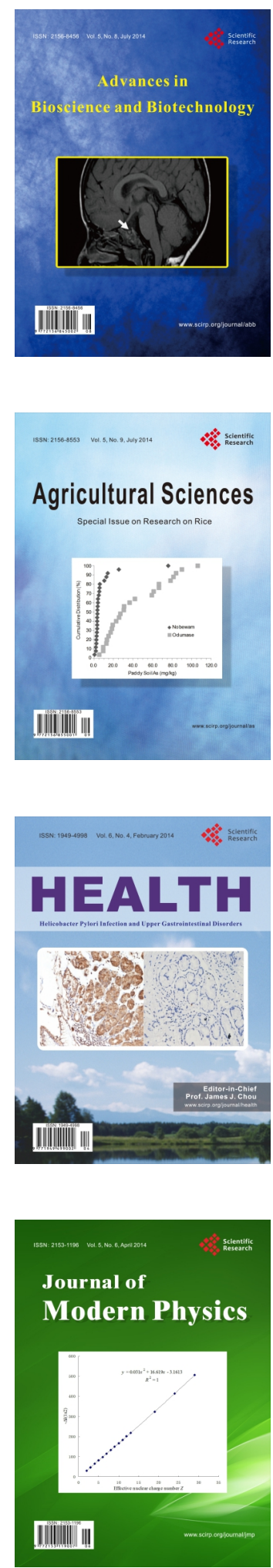
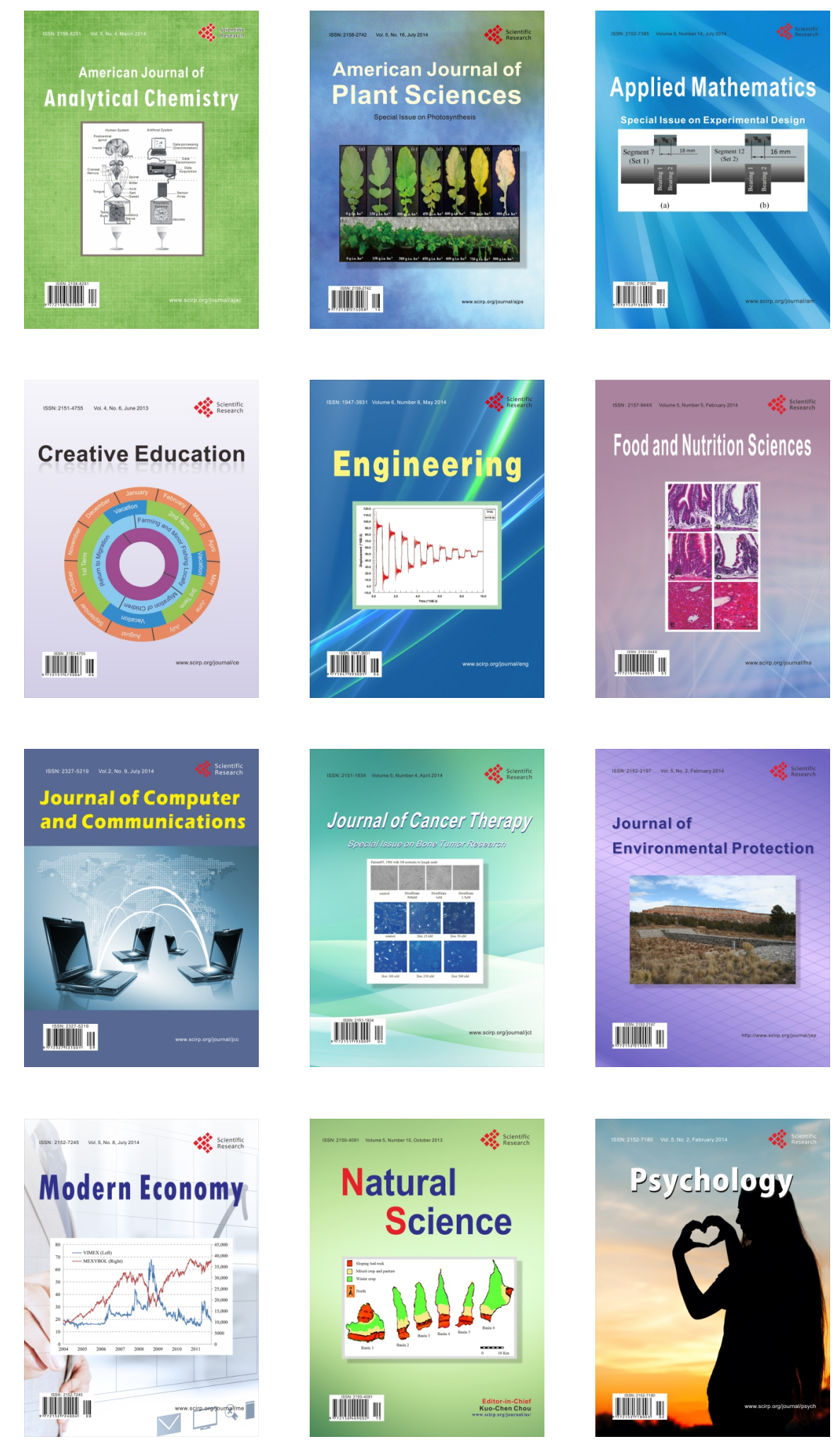